\title{
Economic perspectives of workplace learning
}

Citation for published version (APA):

de Grip, A. (2008). Economic perspectives of workplace learning. In W. Nijhof, \& L. Nieuwenhuis (Eds.), The Learning Potential of the Workplace (pp. 237-253). Sense Publishers.

https://doi.org/10.1163/9789087903725_003

Document status and date:

Published: 01/01/2008

DOI:

10.1163/9789087903725_003

Document Version:

Publisher's PDF, also known as Version of record

Document license:

Taverne

Please check the document version of this publication:

- A submitted manuscript is the version of the article upon submission and before peer-review. There can be important differences between the submitted version and the official published version of record.

People interested in the research are advised to contact the author for the final version of the publication, or visit the DOI to the publisher's website.

- The final author version and the galley proof are versions of the publication after peer review.

- The final published version features the final layout of the paper including the volume, issue and page numbers.

Link to publication

\footnotetext{
General rights rights.

- You may freely distribute the URL identifying the publication in the public portal. please follow below link for the End User Agreement:

www.umlib.nl/taverne-license

Take down policy

If you believe that this document breaches copyright please contact us at:

repository@maastrichtuniversity.nl

providing details and we will investigate your claim.
}

Copyright and moral rights for the publications made accessible in the public portal are retained by the authors and/or other copyright owners and it is a condition of accessing publications that users recognise and abide by the legal requirements associated with these

- Users may download and print one copy of any publication from the public portal for the purpose of private study or research.

- You may not further distribute the material or use it for any profit-making activity or commercial gain

If the publication is distributed under the terms of Article $25 \mathrm{fa}$ of the Dutch Copyright Act, indicated by the "Taverne" license above, 


\section{CHAPTER 2}

\section{Economic perspectives of workplace learning}

IN VARIOUS FIELDS OF ECONOMIC Science the importance of workplace learning has been recognised for a long time. Human capital theory particularly focuses on the returns to "on-the-job training" and "experience", and its relation with labour turnover. Others found that "learning by doing" is a major determinant of firm productivity, and noticed the relevance of High Performance Workplaces. More recently, labour economists are opening the black box of human capital by analysing the importance of different kinds of skills developed by formal or informal training, and studies on the determinants of the development of knowledge

\subsection{Introduction}

FOR ALMOST HALF A CENTURY, economic science has been analysing workplace learning, as part of the study of human capital. From an economic perspective, all activities related to learning can be seen as an investment. The idea is that individuals have to make an effort which will pay off later. The investment character of learning activities is based on the 'human capital theory', which was launched by a supplement to the Journal of Political Economy on 'Investments in Human Beings' in 1962. Actually, the main focus of human capital theory was on the 'rate of return' on the investments in the level of someone's initial education. However, in the 1962 Journal of Political Economy supplement, two seminal papers by Gary Becker and Jacob Mincer had already been focusing on 'on-the-job training' and 'learning from experience':

"Graduation from some level of schooling does not signify the completion of a training process. It is usually the end of a more general and preparatory stage, and the beginning of a more specialized and often prolonged process of acquisition of occupational skill, after entry into the labour force. This second stage ranges from formally organized activities such as apprenticeships and other training programs to the informal processes of learning from experience." (Mincer, 1962, p. 50).

Other economists derived the importance of workplace learning from their findings that firms become more productive when their workforce becomes more experienced (Arrow, 1962). Of a more recent date is the economic literature on the impact of the High Performance Workplace, where workers are expected to be 
employed in jobs with a high learning potential, on the performance of the firm (for instance Black and Lynch, 2001).

However, in economics, the term workplace learning is often not used explicitly. Instead, economists distinguish between 'on-the-job training' and 'learning by doing'. It should be noted that in human capital theory the concepts used are all related to the investment context. In this context, it is particularly important whether it is the firm or the workers who pay the costs of learning activities, and whether it is the firm or the workers who will benefit from these activities. For this reason, it is more appropriate to distinguish between general and firm-specific education and training, irrespective of whether this training takes place in the workplace or not (see Becker, 1962), and to study workplace learning activities which are an automatic by-product of productive work, i.e. learning by doing. Obviously, the latter does not necessarily mean that this learning is free, as, for instance the learning by doing of apprentices often implies that they are less productive than youngsters who do not perform any tasks which are intended to offer learning opportunities.

Moreover, it should be mentioned that in economic science it is not important whether the things someone learns refer to knowledge or skills: as both can make a worker more productive, there is no conceptual difference from an economic point of view. There is therefore no tradition of a careful use of these terms in economic science. It only seems to be more or less a matter of the personal taste of the author, without any discussion of the terminology. Some authors prefer the term 'knowledge', whereas others refer to 'skills', or 'competencies'. On the other hand, the terms used are often related to the focus of a study. For instance, in the literature on the impact of technological and organisational innovations, most authors refer to computer skills, communication skills, etc., whereas in the literature on economic growth, and in the economic policy literature on the 'knowledge economy', most authors use the term 'knowledge'. As this chapter refers to the economic perspectives of workplace learning, the tradition in economics will be followed: not bothering about these terminological issues and using human capital,'skills, knowledge, competencies more or less as synonyms.

This chapter will discuss the economic literature on workplace learning, starting with the contributions of human capital theory, screening theory, and the literature on skill obsolescence and the High Performance Workplace. Furthermore, it considers the increasing importance of behavioural and people skills, and the way in which most firms attempt to reduce shortages in these skills among their technical workforce. Then follows an elaboration of the relation between workplace learning and labour turnover, and the complementarities of formal training and informal workplace learning. The latter section gives a presentation of some recent evidence on the relevance of informal learning for the 'knowledge development' of the Dutch working population. 


\subsection{Human Capital Theory}

As mentioned in the introduction, the founding fathers of the human capital theory have already dealt with workers' learning in the workplace. We will here first discuss the contributions on economic insights about workplace learning of three of them: Garry Becker, Jacob Mincer and Sherwin Rosen.

Becker (1962) particularly focuses on the distinction between general and firmspecific on-the-job training. He defined general training as the training which enhances a worker's productivity in all kinds of jobs, whereas firm-specific training only makes a worker more productive in the firm where he or she is employed. General on-the-job training may, for instance refer to vocational skills (bricklaying, diagnoses of illnesses, etc.) that can also be applied in other firms in the same sector of the economy. Moreover, it refers to the learning of skills that can be applied across the economy such as communication skills, accuracy, etc. Firm-specific on-the-job training, on the other hand, refers to the acquisition of knowledge about machines or procedures which are only used in the firm where a worker is employed, or knowledge about specific characteristics of the products and clients of the firm.

The distinction made by Becker has two important consequences. First, only general training will increase a worker's future wage, because only the acquisition of skills that can be applied elsewhere will increase a worker's value in the labour market, whereas firm-specific skills are useless when a worker moves to another firm. Second, firms will only pay the costs of firm-specific training, because they will not benefit from investments in the general skills of their workforce, since the benefits of the higher productivity of workers who have acquired general skills are entirely reflected in higher wages. Workers therefore have to pay the costs of general training themselves. This is usually reflected in a lower wage during the period in which they are trained on the job. For this reason, workers who are employed as apprentices or trainees earn a wage which is below their productivity.

In Becker's model, it is not relevant to distinguish between formal training and more informal workplace learning, as both activities involve certain costs. These may refer to the costs of learning material or the costs of a supervisor as well as to the lower productivity of the trainee during the time he is involved in attending a course or workplace learning. In economic theory, the latter costs are known as 'opportunity costs'.

Mincer $(1962,1974)$ deals with workplace learning in quite a different way: he particularly focuses on the impact of workers' experience on their productivity, as measured by their earnings. For this purpose, Mincer developed a so-called 'earnings function', which relates workers' wages to their educational background and work experience. The log transformation of workers' incomes enables the estimated coefficients to be interpreted as the rates of return on an additional year of education or experience. Table 2.1 presents Mincer's seminal estimation results on the relation between the human capital and the annual earnings of the white male US labour force in 1959. The first equation shows that the level of a worker's initial education only explains 7 per cent of the variation in the logarithm of 
income. However, when experience, as a proxy for workplace learning, is included, 28 per cent of the variation can be explained. It is interesting to see that Mincer not only included a worker's years of experience in the equation, but also the square of this number of years. The estimation results show that an additional year of experience gives the worker on average a return of 8 per cent. However, the negative coefficient of the square term shows that the rate of return levels off when workers acquire more and more years of experience. This shows that, at some point in their career, workers are virtually no longer learning anything during their work.

Table 2.1: Estimates of the relation between initial education (S) and work experience $(X)$ and the annual earnings $(y)$ of white men working in the United States in 1959

$\begin{array}{rrr}\ln y=7.58+ & 0.070 \mathrm{~S} & \\ \quad(43.8) & \mathrm{R}^{2}=0.067 \\ \ln y=6.20 & 0.107 \mathrm{~S}+0.081 \mathrm{X}-0.0012 \mathrm{X}^{2} & \\ (72.3)(75.5)(-55.8) & \mathrm{R}^{2}=0.285\end{array}$

Source: Mincer (1974, Table 5.1)

( $t$-statistics in parentheses)

Actually, Rosen (1972) dealt more explicitly with workplace learning than Becker and Mincer. He particularly focused on 'the learning potential' of a job: "The fundamental hypothesis is that individuals learn from their working experience. Firms supply learning opportunities in the form of different types of work-learning activities, and to that extent engage in a kind of joint production, for learning is a by-product of market goods production" (Rosen, 1972, p. 327).

By connecting the market for learning opportunities with the market for jobs, Rosen argues that in the labour market there actually are 'package deals' in which workers simultaneously sell the services of their skills and purchase a job that offers a particular opportunity to learn. Obviously, the latter is not without cost. From the perspective of the worker, accepting a job with a high learning potential can be a good strategy to maximise their lifetime income, i.e. in their early career, workers may apply for a job with a high learning potential, as this job will be a good stepping stone for their further careers. Sicherman and Galor (1990) further developed Rosen's theoretical work in their theory on career mobility. In their model, part of the returns on initial education is in the form of higher probabilities of occupational upgrading within or across firms, due to the learning potential of their job. When workers opt for jobs with a high learning potential, their wages will be lower, but their opportunities for upward career mobility will be higher. Examples of these kinds of jobs are trainee jobs in large firms.

In the 1970 s, the human capital theory was challenged by the signalling or screening theory (for instance Spence, 1973). This theory claimed that initial education does not increase a person's productivity. Instead, initial education only enables someone to signal that he or she is a high-ability worker. Thurow (1975) stated that initial education does not produce marketable skills without any job experience. Initial education merely indicates a person's trainability, i.e. the 
training costs a firm incurs to make someone productive in the firm. This trainability not only refers to workers' cognitive learning abilities but also to their adaptability and work discipline. A higher level of initial education only helps someone to obtain a better place in the 'labour queue' for the most attractive jobs. The screening theory increases the relevance of workplace learning for the productivity of workers. Actually, it is no longer the level of initial education which makes some more productive, but only the skills learned on the job. However, just like the human capital theory, the screening theory does not distinguish between formal off-the-job training courses and workplace learning. Training is implicitly seen as a mixture of formal vocational training and informal training.

\subsection{The costs of workplace training}

Although workplace learning avoids the direct training costs and opportunity costs of formal off-the job training, it is not without costs. As mentioned above, workplace learning may include the costs of a supervisor as well as the opportunity costs due to the lower productivity of the trainee who is learning on the job. However, these opportunity costs are related to the quality or the intensity of the training. In a study of the quality of apprenticeship training in the Netherlands, Smits (2005) distinguished between firms which train apprentices because of the benefits during the training period and firms which train apprentices because of the expected benefits in the post-training period. Firms which train because of the current benefits from cheap trainees will offer low-quality training, because for these firms the productivity of an apprentice should be higher than the training costs. In these firms, apprentices will often do unskilled work in which they will be fully productive (Soskice, 1994). However, firms which train apprentices because of the future benefits will offer high-quality training, although there may be a conflict of interest between the firm and the apprentice with respect to the firmspecific or general character of the training. As Table 2.2 shows, the percentage of training firms which have a net benefit from the apprentices during the training period is rather high. Two-thirds of the training firms in the Netherlands state that they earn back the costs of employing apprentices during the training period. In business services particularly, it seems to be more difficult to gain net benefits from apprentices during the training period.

Franz and Soskice (1995) and Acemoglu and Pischke (1998) state that firms which train newly hired workers also have an important informational advantage with respect to the abilities and motivation of the trainees, because these firms can observe the trainees during their initial training period. Autor (2001) showed that this also holds for temporary work agencies that offer free general training to temporary workers. The information the training firms obtain about their trainees enables them only to offer a job to those trainees who have high abilities and good motivation. Obviously, this selection advantage only holds for the firms which train new hires because of the future benefits of maintaining a skilled workforce. 
Table 2.2: Percentage of training firms in the Netherlands that report apprentices have net benefits during the training period.

\begin{tabular}{ll}
\hline Manufacturing & 73 \\
Garages & 87 \\
Building & 65 \\
Hotel and catering sector & 76 \\
Business services & 45 \\
Wholesale \& retail trade & 59 \\
Non-profit & 71 \\
Total & 66 \\
\hline
\end{tabular}

Source: Borghans et al., 2000.

In her analysis of the quality of the apprenticeship training programmes of Dutch firms, Smits (2005) distinguished different aspects of the quality of training programmes: the complexity of production tasks, the learning content of production tasks, the time for formal learning activities at the workplace and the time for supervision and instruction. She showed that there is a considerable variation in training quality between different firms. As expected, she found that there is a relation between training quality and the training motives of a firm. Firms which recruit apprentices because of current benefits offer lower quality training than firms which have apprentices to meet their future demands for skilled workers.

\subsection{Skill obsolescence}

It should be noted that Mincer's estimates of the returns on experience, as a proxy for workplace learning', actually measure the net effect of workers' experience, because the knowledge workers have acquired in the past will depreciate in the course of time (Rosen, 1975). The notion of skill obsolescence is, of course, quite obvious from a human capital point of view. In a similar way to physical capital goods, workers' human capital will also depreciate due to technical or economic obsolescence. The first refers to the deterioration of physical or mental capacities due to ageing, the latter to the fact that the value of particular skills will decrease due to, for instance technological innovations in the production process which affect the contents of jobs (De Grip \& Van Loo, 2002).

Technological innovations, however, might also give an impetus to workplace learning, because workers often learn the skills that are needed to work with a new technology in the workplace. This explains why workers who are employed in industries which are characterised by high rates of technological change are better able to retain their productivity at an older age, and have later retirement ages than workers in sectors which are less dynamic. Although the workers in these sectors of industry will face more skill obsolescence due to technological developments, the net effect of technological change on their human capital is positive, because 
they continuously acquire new skills related to the new technologies (Bartel \& Sicherman, 1993).

Weinberg (2002) found that the skills workers developed with respect to an obsolete technology may also be transferable to the new technology. In his analysis, Weinberg estimates the development of the returns on experience of male workers between 1959 and 1997 for both high school graduates and college graduates in the US. Whereas the returns on experience for college graduates have been flat, the returns on experience among high school graduates have increased. Remarkably, unlike the college graduates, experienced high school graduates also more often adopted new information technologies than high school graduates with less experience. This shows that, although more experienced high school graduates have greater stocks of skills which are related to the old technology, this does not prevent them adopting the new technology. This indicates that the skills that more experienced high school graduates learnt on the job with respect to the older modes of production are transferable to the new technologies. As mentioned above, Weinberg did not find similar results for college graduates. For these higher skilled workers, workplace learning with respect to older technologies does not make more experienced workers more valuable than younger graduates who more recently acquired more up-to-date skills at university.

\subsection{High Performance Workplace}

However, in economic science, it was not only the labour economists involved in the development of the human capital theory and the screening theory who have been analysing the role and impact of learning at the workplace. Again, at the beginning of the 1960s, Arrow (1962) emphasised the importance of unstructured workplace learning, not from the perspective of the individual worker, but from the perspective of the firm. He was involved in explaining the puzzle of why the increase in per capita income cannot be explained by increases in the capital-labour ratio. Obviously, the missing explanation for part of the economic growth is the increase in knowledge, including technological knowledge, which enables firms to optimise their production processes. Arrow argues that this increase in knowledge is acquired by learning that is the product of experience:

"Learning can only take place through the attempt to solve a problem and therefore only takes place during activity" (Arrow, 1962, p.155).

Workplace learning is therefore a more or less automatic by-product of the regular production process of a firm, which he labelled 'learning by doing'. Arrow illustrated this process of learning by doing by what is known as the 'Horndal effect':

"The Horndal iron works in Sweden had no new investment (and therefore presumably no significant change in its methods of production) for a period of 15 years, yet productivity (output per man-hour) rose on average close to 2 
per cent per annum. We find again steadily increasing performance which can only be imputed to learning from experience" (Arrow, 1962, p.156).

From a similar firm perspective, in the 1990s economists became more interested in the effects of the organisation of the production process. In the literature on 'skill-based technological change', the shifts in the skills demanded in many jobs were found to be related to the organisational changes that accompany the diffusion of ICT: flat hierarchies, autonomous work groups and teamwork (Bresnahan, Brynjolfsson \& Hitt, 2002). These transformations of workplaces induced a growing demand for workers with both cognitive skills and "people skills' (Autor, Katz \& Krueger,1998), while Lindbeck and Snower (2000) argued that, in addition, more flexible and 'multi-skilled workers' are required.

In particular, the notion of 'Innovative Work Practices' in the so-called 'High Performance Workplace (HPW)', originally developed in the discipline of Human Resource Management, has been used to explain the improved performance of a firm (for instance Ichniowski, Shaw \& Prennushi (1997). Although the HPW is usually not clearly defined, many authors include (1) delegation of responsibility to autonomous teams, (2) job rotation, (3) performance-related earnings and (4) training to support organisational change, whereas some authors relate the HPW to Total Quality Management, including 'quality circles' (see Handel \& Levine (2004) for an overview). These characteristics of the HPW form a cluster of complementary human resource practices that have a great positive effect on the productivity of the firm, while changes in individual human resource practices have little or no effect on a firm's productivity (Ichniowski, Shaw \& Prennushi, 1997).

Obviously, workplace learning is at the heart of the HPW. First, it is a necessary complement to the continuously changing and increasing demand for skills in the jobs involved. Second, offering jobs with a high learning potential will increase workers' motivation (Zwick, 2006). Workplace learning is particularly important because of the growing demand for workers with problem-solving skills, high level communication and social skills (Dickerson \& Green, 2004) and 'multi-skilled workers' (Lindbeck \& Snower, 2000). The latter argued that the growing demand for multi-skilled workers induces a shift from 'intratask learning' to 'intertask learning':

"Intratask learning is learning by doing in the traditional sense (Arrow, 1962): the more time a worker spends at a particular task, the more skilful he becomes at performing that task and thus the greater becomes his productivity from this activity. Intertask learning, by contrast, arises when a worker can use the information and skills acquired at one task to improve his performance at other tasks" (Lindbeck \& Snower, 357).

Intertask learning mainly takes place through job rotation within or between teams. It obviously includes the improvement of a worker's 'people skills', and attempts to contribute to a worker's problem-solving skills.

A recent survey among HRM managers of firms in the high-tech metalelectronics sector in the Netherlands confirmed the increasing importance of 
behavioural and people skills for the technical employees in these firms. Seventythree per cent of these HRM managers expect an increasing demand for more flexible workers in the next five years, 72 per cent an increasing demand for problem-solving competencies, 63 per cent an increasing demand for workers who can display initiative, and 58 per cent an increasing demand for communicative competencies (De Grip, Van Loo \& Sieben, 2005).

Table 2.3: Ways in which shortages in the competencies of technical workers in the Dutch metal-electronics sector are reduced (2004) (\% of firms)

Competencies

Formal Informal Learning No course or training by doing shortage training

\begin{tabular}{lllll}
\hline Technical knowledge and skills & 55 & 61 & 23 & 11 \\
Language skills & 30 & 9 & 19 & 44 \\
Computer/IT skills & 33 & 26 & 24 & 22 \\
Management skills & 44 & 14 & 17 & 27 \\
Teamwork skills & 14 & 25 & 32 & 31 \\
Problem-solving skills & 8 & 33 & 32 & 27 \\
Communication skills & 37 & 20 & 19 & 24 \\
Commercial skills & 22 & 17 & 15 & 47 \\
Coping with changes & 12 & 31 & 33 & 27 \\
Flexibility & 11 & 27 & 38 & 27 \\
Planning and organization skills & 28 & 24 & 25 & 27 \\
Creativity & 4 & 26 & 28 & 44 \\
Initiative & 8 & 23 & 37 & 34 \\
Contact with other cultures & 2 & 10 & 37 & 52 \\
Learning skills & 6 & 23 & 32 & 39 \\
\hline
\end{tabular}

Note: The percentages are not related to each other, and therefore do not add up to $100 \%$. Source: ROA/Employers panel Metalectro 2004

Table 2.3 shows that, apart from communicative skills, most firms attempt to reduce shortages in these skills among their technical workforce by informal training or learning by doing instead of formal training. Thirty-eight per cent of the firms try to reduce shortages in the flexibility of their workers by means of 'learning by doing', whereas only 11 per cent of the firms do this by means of formal training or a combination of the two. For improving workers' capacities to take initiative and workers' problem-solving skills, 37 per cent and 32 per cent respectively of the firms rely on learning by doing. More generally, the table shows that formal training is particularly used to reduce shortages in vocational 
competencies, whereas almost all the shortages in behavioural and people skills are mainly reduced by workplace learning in the form of informal training and/or learning by doing.

\subsection{Workplace learning and labour turnover}

In human capital literature, the relation between workplace learning and labour turnover is also an important issue. Obviously, it is related to the question as to whether the firm or the worker can reap the benefits of the investments in workplace learning. As mentioned above, from an investment perspective there is no need to distinguish between formal and informal workplace training. However, the difference between general and firm-specific training is important here, as general skills also increase workers' productivity in other firms, whereas firmspecific skills only make a worker more productive in the firm where he or she is working. Firm-specific training will thus reduce labour turnover, whereas general training makes a worker more attractive to other firms.

In a comparative study, the OECD (1993) showed that there are very large differences in the incidence of in-house training of new hires between various countries. Whereas, in the early 1990s, the incidence of in-house training of new recruits with less than one year of tenure was almost 80 per cent in Japan, it was less than 10 per cent in the US. Blinder and Krueger (1996) attribute the low level of workplace training in the US to the high turnover of new recruits there. When firms are not certain that they can reap the benefits of investments in the training of the workforce, they will be reluctant to make these investments. Acemoglu and Pischke (1998) developed a model that emphasises the endogenous trade-off between training and labour turnover. When firms train their workers, this will reduce labour turnover, as these firms are attractive employers, whereas firms which do not invest in the training of their workers will face a high turnover. Their model shows that this trade-off can lead to multiple equilibria. Whereas in the low training equilibrium labour turnover is high, in the high training equilibrium the number of workers leaving is low. Acemoglu and Pischke show that the German apprenticeship system is a good example of the high training equilibrium. Lynch's (1993) finding that young workers who received training are less likely to leave their employer, also confirms the model of Acemoglu and Pischke.

\subsection{Formal training, workplace learning and knowledge development}

In the human capital literature, many studies have analysed the effects of training participation on workers' wages (see Bassanini, Booth, Brunello, De Paola \& Leuven, (2005) for a recent overview). Several studies have found high returns on workers' participation in training, although the returns measured vary greatly, due to the way training is defined and measured, differences between countries and the groups analysed, and the way in which studies correct for selectivity and unobserved heterogeneity. In a study of 14 European countries, Brunello (2004) found that having recently attended training increases a worker's income by about 
12 per cent. Blanchflower and Lynch (1994) found a similar result for young people in the US who participated in employer-provided training. However, Goux and Maurin (1998) found that the returns on training in France were close to zero, when they corrected for selectivity.

Moreover, it is not only the workers who benefit from workers' participation in training. Dearden, Reed and Van Reenen (2006) found that the effects of training on wages are about half that of the effects on firms' productivity. In an analysis of longitudinally-linked administrative and survey data on firms in manufacturing, trade and the building sector, Van Loo and De Grip (2003) found evidence for a mutual reinforcement of training participation and firm performance. They found that when the employees of a firm participate in one additional course this will increase the profit per employee by $€ 12,500^{1}$. Moreover, Van Loo and De Grip found that an increase in the profit per employee by $€ 1,000$ will cause an increase in the average training participation of 0.01 course. Although the latter effect is much smaller than the effect of training participation on a firm's profit, the mutual reinforcement between training participation and a firm's profit shows that there is a vicious circle which explains why some 'rich' firms have high training participation rates, whereas in other 'poor' firms the workforce hardly participates in training. Obviously, the results of Van Loo and De Grip (2003) show that it is attractive to firms to follow the training route.

However, one may wonder whether it is really the participation in formal training that makes the difference. When workers have to acquire additional competencies, they will learn most when they participate in a training course and practise the new skills in their job. Borghans, Golsteyn and De Grip (2006) found that when employers stimulate workers' participation in formal courses, these workers will also spend more time on informal learning in the workplace. However, as the above-mentioned studies of the effects of participation in formal training do not measure the time spent on workplace learning, all the benefits of the knowledge and skill acquisition of the workers will be attributed to their participation in formal training. Human capital studies which only include workers' experience as a proxy for workplace learning will overestimate the effects of formal training, because they do not include the time actually spent on informal workplace learning. So it is the complementarities between formal training and informal workplace learning which explain why participating in a course for only a few days can have such large effects on workers' earnings and firms' profits.

Borghans et al. (2006) provide detailed information on the working time Dutch workers spend on activities from which they learn on the job. On average, workers spend 31 per cent of their working time on such activities (see Table 2.4). Obviously, this is much more than the time they spend on participation in formal training. Actually, only 6 per cent of the time workers are involved in activities from which they learn refers to their participation in formal training courses; the remaining 94 per cent refers to the time they spend on informal learning activities.

Table 2.4 also shows that the time men and women spend on workplace learning hardly differs. When looking at the educational backgrounds of the workers, it is striking that particularly workers with only general secondary education less often 
have opportunities for workplace learning, whereas university graduates more often perform tasks from which they can improve their competencies.

Table 2.4: Percentage of the working time that Dutch employees spend on activities from which they learn, by gender and level of education (2005)

Male

Female

Primary education

Preparatory vocational education

General secondary education

Intermediate vocational education

Higher vocational education

University education
30

32

32

29

24

30

33

35

Total

As might be expected, younger workers spend more time on activities which improve their competencies than do older workers. Whereas workers who are 25 years old spend almost 40 per cent of their working time on activities from which they learn, workers who are older than 50 spend less than 25 per cent of their working time on these kinds of activities. Further analyses show that the extent to which workers are involved in activities from which they learn is significantly related to organisational changes. This supports the findings of Bartel and Sicherman (1993) that workers who are employed in a dynamic workplace become more employable and less often retire early.

Borghans et al. (2006) also found that workplace learning is an important determinant of the 'knowledge development' of workers. For this analysis, they developed a measure of knowledge development by asking the respondents to give the knowledge and skills needed to fulfil their current job optimally a value of 100 , and then asking them to value the competencies they had two years ago. Then, the difference between the two values indicates their knowledge development in the last two years. Table 2.5 gives an overview of the results of the analysis. As mentioned above, informal learning has a large positive effect on the knowledge development of workers. It is also interesting to see that, although participation in formal training courses also has a positive effect on workers' knowledge development, the duration of these training courses does not seem to matter. This indicates that it is particularly important that workers regularly participate in short formal training courses, as this is a stimulus for further informal learning in the workplace. Finally, the analysis of Borghans et al. (2006) shows that youngsters, and particularly those who recently left school, also have a greater increase in the knowledge relevant to their job. Obviously, this can also be attributed to a combination of formal training and informal learning in the workplace. 
Table 2.5: Determinants of knowledge development

\begin{tabular}{lll}
\hline & B & Std. Error \\
Constant & 17.313 & $2.995^{* * *}$ \\
Male & -0.332 & $0.034^{* * *}$ \\
Age & -1.782 & $0.675^{* * *}$ \\
Preparatory vocational education & 4.131 & $2.475^{*}$ \\
General secondary education & 3.862 & 2.585 \\
Intermediate vocational education & 1.789 & 2.475 \\
Higher vocational education & 2.285 & 2.451 \\
University education & 2.154 & 2.527 \\
Participation in formal training & 1.386 & $0.689^{* *}$ \\
Duration of training courses & -0.001 & 0.002 \\
Informal learning & 6.940 & $2.278^{* * *}$ \\
Recently left school & 8.546 & $1.179^{* * *}$ \\
\hline
\end{tabular}

Level of significance: $*=10 \%, * *=5 \%, * * *=1 \%$.

\subsection{Conclusions}

Although in economic literature other terms are usually used, such as 'training on the job' and 'learning by doing', there are many studies which analyse workplace learning. Obviously, from the economic perspective, workplace learning is considered to be an investment decision for both the worker and the firm. For this reason, economics studies particularly analyse the returns on these investments in workplace learning from the perspective of the human capital theory.

Another interesting subject in economic literature is the relation between on the one hand technological and organisational innovations and on the other the risks of skill obsolescence and the opportunities for workplace learning offered by these innovations. Furthermore, since the last decade, many studies have been published on the High Performance Workplace. In this HPW, workplace learning plays an important role. Moreover, the HPW can be linked to the need for intertask learning and the importance of behavioural and 'people skills'. Moreover, labour economists nowadays have a greater interest in opening the black box of human capital by distinguishing between different skills or competencies.

Finally, a recent study was presented in which the impact of workplace learning on the knowledge development of workers was measured. It is an example of the approach economists like to follow in empirical research. Without bothering too much about conceptual issues, they attempt to develop an operational measure which may contribute to both our insights about the relevance of workplace learning and the critique of others who may take over the baton. 


\section{REFERENCES}

Acemoglu, D., \& Pischke, J. (1998). Why do firms train? Theory and evidence. Quarterly Journal of Economics, 110, 355-381.

Arrow, K.J. (1962). The Economic Implications of Learning by Doing. Review of Economic Studies, 24, 155-173.

Autor, D. (2001). Why Do Temporary Help Firms Provide Free General Skills Training. Quarterly Journal of Economics, 116, 1409-1448.

Bartel, A.P., \& Sicherman, N. (1993). Technological Change and Retirement Decisions of Older Workers. Journal of Labor Economics, 11, 162-183.

Bassanini, A., Booth, A.L., Brunello, G., De Paola, M., \& Leuven, E. (2005). Workplace Training in Europe. IZA-Discussion paper n. 1640, Bonn: IZA.

Becker, G.S. (1962). Investment in Human Capital: A Theoretical Analysis. Journal of Political Economy, 70, 9-49.

Black, S.E., \& Lynch, L.M. (2001). How to compete: The impact of workplace practices and information technology on productivity. The Review of Economics and Statistics, 83, 434-445.

Blanchflower, D., \& Lynch, L. (1994). Training at work: A comparison of the US and British youths. In: L. Lynch, L. (Ed.) Training and the Private Sector: International Comparisons. Chicago: University of Chicago Press.

Blinder, A., \& Krueger, A. (1996). International differences in turnover: a comparative study with emphasis on the US and Japan. Pacific Economic Review, 1,27-57.

Borghans, L., Golsteyn, B., \& Grip, A. de (2006). Meer werken is meer leren. Determinanten van kennisontwikkeling, 's-Hertogenbosch: CINOP.

Borghans, L., Smits, W., Vlasblom, J., \& Jacobs, A. (2000). Leren en werken in het Nederlandse beroepsonderwijs. Ontwikkelingen in de BBL. ROA-R-2000/2, Maastricht: Research Centre for Education and the Labour Market.

Bresnahan, T.F., Brynjolfsson, E., Hitt, L.M. (2002). Information Technology, Workplace Organization, and the Demand for Skilled Labor: Firm-Level Evidence. Quarterly Journal of Economics, 117, 339-376.

Brunello, G. (2004). On the Complementarity between Education and Training in Europe. In: D. Checchi and C. Lucifora (Eds.) Education, Training and Labour Market Policies in Europe. Houndmills/New York, Palgrave Macmillan.

Dearden, L., Reed, H.; \& Van Reenen, J. (2006). The Impact of Training On Productivity and Wages: Evidence from British Panel Data. Oxford Bulletin of Economics and Statistics, 68, 397-421

De Grip, A., \& Van Loo, J. (2002). The Economics of Skills Obsolescence: A Review. In: A. De Grip, J. Van Loo, J. and K. Mayhew (Eds.). The Economics of Skills Obsolescence, Research in Labor Economics, Amsterdam/Boston: JAl Press, 2002. vol. 21 (pp.1-26).

De Grip, A., Van Loo, J., \& Sieben, I. (2005). Arbeidsmarktmonitor Metalektro 2004, ROA-R-2005/5, Maastricht: ROA.

Dickerson, A., \& Green, F. (2004). The Growth and Valuation of Computing and Other Generic Skills. Oxford Economic Papers , 56, 371-406.

Franz, W., \& Soskice, D. (1995). The German Apprenticeship System. In: F. Buttler, W. Franz, R. Schettkat \& D. Soskice (Eds.). Institutional Frameworks and Labor Market Performance (pp. 208234). London/New York: Routledge

Goux, D. \& Maurin, E. (1998). Returns to continuous training: evidence from French worker-firm matched data. Labour Economics, 7, 1-19.

Handel, M.J., \& Levine, D. (2004). Editor's Introduction: the effects of New Work Practices on Workers, Industrial Relations, 43, 1-43.

Ichniowski, C., Shaw, K., \& Prennushi, G. (1997). The effects of human resource management practices on productivity: A study of steel finishing lines. American Economic Review, 87, 291-312.

Lindbeck, A., \& Snower, D. (2000). Multi-Task Learning and the Reorganization of Work. From Tayloristic to Holistic Organization. Journal of Labor Economics, 18, 353-376. 
Lynch, L.M. (1993). The Economics of Youth Training in the United States. Economic Journal, 103,1292-1302.

Mincer, J. (1962). On-the-Job Training: Costs, Returns, and Some Implications. Journal of Political Economy, 70, 50-79.

Mincer, J. (1974). Schooling, Experience and Earnings, New York: National Bureau of Economic Research.

OECD (1993). Employment Outlook 1993. Paris: OECD.

Rosen, S. (1972). Learning and Experience in the Labour Market. Journal of Human Resources, 7, 326342.

Rosen, S. (1975). Measuring the Obsolescence of Knowledge. In: F.T. Juster (Ed.), Education, Income and Human Behavior, New York: Carnegie Foundation. (pp.199-232).

Sicherman, N., \& Galor, O. (1990). A Theory of Career Mobility. Journal of Political Economy 98, 169-192.

Smits, W. (2005). The Quality of Apprenticeship Training. Conflicting Interests of Firms and Apprentices, Maastricht: Maastricht University (Ph.D. Thesis).

Soskice, D. (1994). Reconcilling Markets and Institutions: The German Apprenticeship System. In L. Lynch, L. (Ed.) (pp. 25-60). Training and the Private Sector: International Comparisons. Chicago: University of Chicago Press.

Spence, O.F. (1973). Job Market Signaling. Quarterly Journal of Economics, 87, 355-374.

Thurow, L.C. (1975). Generating Inequality. New York: MacMillan.

Van Loo, J. \& De Grip, A. (2003). Loont het investeren in het personeel?, ROA-R-2003/1, Maastricht: ROA

Weinberg, B.A. (2002). New Technologies, Skills Obsolescence; and Skill Complementarity. In: De Grip, A., J. Van Loo \& K. Mayhew (eds.), The Economics of Skills Obsolescence, Research in Labor Economics, 21, (pp. 101-118). Amsterdam/Boston: JAI Press, 101-118.

Zwick, Thomas (2006). The Impact of Training Intensity on Establishment Productivity. Industrial Relations 45, 26-46

\section{NOTES}

${ }^{1}$ Van Loo and De Grip (2003) found similar large effects of training participation on productivity and the Return on Sales. 